\title{
Structure, litter fall, decomposition, and detritus dynamics of mangroves in a Mexican coastal lagoon with an ephemeral inlet
}

\author{
Francisco J. Flores-Verdugo ${ }^{1}$, John W. Day, $\mathrm{Jr}^{2}{ }^{2}$ \& Raquel Briseño-Dueñas ${ }^{1}$ \\ ${ }^{1}$ Instituto de Ciencias del Mar y Limnología, Universidad Nacional Autónoma de México, Estacion Mazatlán, Mazatlán, \\ Sinaloa, Apdo. 811, México \\ ${ }^{2}$ Coastal Ecology Institute, Center for Wetland Resources, Louisiana State University, Baton Rouge, Louisiana 70803, USA
}

\begin{abstract}
Dynamics of litter fall, decomposition, litter transport, and forest structure of white mangroves Laguncularia racemosa Gaertn were studied in a small coastal lagoon on the Pacific coast of Mexico from June 1979 until October 1981. The lagoon is characterized by an ephemeral inlet which is open to the ocean for 3 to 4 mo per year during the wet season. Total litter fall was $1100 \mathrm{~g} \mathrm{dw} \mathrm{m}^{-2} \mathrm{yr}^{-1}$. Leaf decomposition was much more rapid in litter bags placed in the water $\left(0.26 \mathrm{mo}^{-1}\right)$ than in bags placed on the dry forest floor $\left(0.05 \mathrm{mo}^{-1}\right)$. Experimental $20 \mathrm{~g}(\mathrm{dw})$ samples of leaves placed on the forest floor were flushed out after the opening of the lagoon inlet. We estimate that almost $90 \%$ of total litter fall was exported from the mangroves to the lagoon waters and that most of this was flushed to the ocean. This is due to a number of factors. Litter decomposition on the dry forest floor is very slow, peak litter fall occurs just before the onset of the rainy season, and the rapid outflow of accumulated water when the inlet opens flushes almost all accumulated detritus from the forest floor and lagoon sediments. Structural, productivity, and litter transport patterns of this system suggest that mangrove forests in lagoons with ephemeral inlets do not fit well into existing classification schemes.
\end{abstract}

\section{INTRODUCTION}

Much of the Pacific shore of Mexico is a strand plain lagoonal coast characterized by numerous coastal lagoons (Lankford 1977). The larger systems have permanent inlets, while smaller lagoons (on the order of $1.0 \mathrm{~km}^{2}$ ) are much more numerous and generally have ephemeral inlets. For example, there are 18 small lagoons in the $60 \mathrm{~km}$ of coast north of Mazatlán, Mexico (van der Heiden \& Hendrickx 1982), the zone which includes our study site. All but one have ephemeral inlets which are open to the ocean for 3 to 4 mo during the rainy season. Most of the lagoons are bordered by a narrow mangrove fringe composed almost entirely of Laguncularia racemosa Gaertn (white mangrove). There is interest in the mangroves in these lagoons because considerable recent literature indicates that mangroves are often productive, that they serve as habitat and a source of food for many lagoon and nearshore species, and that mangrove organic detritus is exported to lagoon and nearshore coastal waters (Carter et al. 1973, Lugo \& Snedaker 1974, Odum \&
Heald 1975, Pool et al. 1975, Brown \& Lugo 1982, Odum et al. 1982).

This study was undertaken to measure the structure, litter production, and decomposition of the mangroves of El Verde Lagoon, a small coastal lagoon with an ephemeral inlet. In designing the study, we relied on the model of mangrove structure and productivity which has evolved over the past decade based mainly on the description of Lugo \& Snedaker (1974). They identified several major mangrove community types which result from differences in soil type, nutrient input, and flushing rate. Each community type has a characteristic structure and range in primary production, litter decomposition, and detritus export. The mangrove forest types are: dwarf (originally called scrub), hammock, fringe, basin, and riverine (see also Brown \& Lugo 1982, Odum et al. 1982). Generally, total biomass, height, litter fall, decomposition, and freshwater turnover increase from dwarf to riverine forests (Pool et al. 1975, 1977, Brown \& Lugo 1982). Mangrove swamps in lagoons with ephemeral inlets were not included in the formulation of this classification. 
Therefore, one of the objectives of this work was to determine how well mangroves in this type of system fit the classification.

Initial observations at El Verde suggested to us that the mangroves should probably be classified as a fringe forest. Although Laguncularia racemosa was the only tree species present in most of the area, tree height and the width of the mangrove zone wcre very similar to those of fringe forests. Flushing characteristics also suggested this. There is strong river flow and tidal flushing for 3 to 4 mo per year, but during the dry season the forests are not flushed at all, leading to an overall moderate level of flushing. Therefore, we hypothesized that, in terms of structure, productivity, decomposition, and export, the mangroves at El Verde would be most like fringe forests.

\section{STUDY AREA}

The study site, El Verde Lagoon, is a small ( $47 \mathrm{ha}$ ), shallow (mean depth $1 \mathrm{~m}$ ) coastal lagoon on the Pacific coast of Mexico near the Tropic of Cancer (Fig. 1; $106^{\circ} 35^{\prime} \mathrm{W}, 23^{\circ} 35^{\prime} \mathrm{N}$ ). The lagoon extends $7 \mathrm{~km}$ along the coast behind a beach-dune system but is no more than a few hundred meters in width. The climate is classified as the driest of the tropical subhumids (García 1973), with mean monthly temperature ranging from $18^{\circ} \mathrm{C}$ in January to $30^{\circ} \mathrm{C}$ in August. Mean annual precipitation is about $630 \mathrm{~mm}$, almost all occurring during the rainy season from July to October (Fig. 2). There is flow in the Quelite River only during the wet season (Fig. 2). Total discharge in 1979 and 1980 was 2.7 and $4.5 \times 10^{7} \mathrm{~m}^{3}$, respectively. Mean annual discharge is approximately 200 times the volume of the lagoon.



Fig. 1. Map of El Verde Lagoon showing distribution of mangroves and location of sampling sites

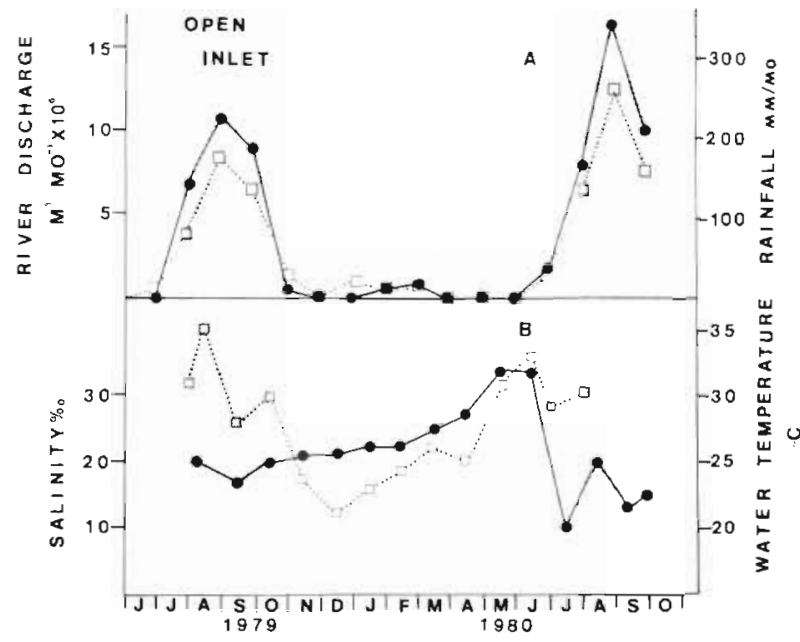

Fig. 2. (A) Discharge of the Quilite River ( $)$ and precipitation $(\square)$ in the study area. (B) Salinity (@) and water temperature ( $\square$ ) in El Verde Lagoon during the study period. Shaded area: time when lagoon inlet was open

The mouth of the lagoon is open only during the wet season. This factor has important ecological ramifications, and it is necessary to understand this seasonality in order to appreciate the dynamics of production and decomposition of mangrove litter. The river, dry during most of the year, begins flow just after the onset of the rainy season. The inlet between the lagoon and the ocean is closed at this time, and water levels in the lagoon rise above sea level, flooding the mangrove fringe. When the water level in the lagoon is high enough (after a few days), it begins to flow over and through the barrier in the inlet and to erode it open. Initially, water flows rapidly out of the lagoon via a shallow channel several hundred meters wide. As the water level in the lagoon decreases, flow is confined to a channel 30 to $40 \mathrm{~m}$ wide; tidal currents enter the lagoon and flow is bidirectional. Flow through the inlet becomes almost solely tidal when river flow diminishes. This lasts for only a short time (several hours to a few days) before wave activity and littoral currents close the inlet. This pattern of river dominance tollowed by mixed tide and river flow and inlet closure occurs a number of times during the wet season depending on the periodicity and intensity of rainfall.

The highest water levels always occur when the inlet is closed, a result of river flow filling the lagoon, and these levels are always higher than the highest level of the sea. Thus, there is a strong hydraulic gradient from the lagoon to the sea. High water levels also occur during spring tides. The mangrove floor is flooded only during these 2 types of events and flooding of the floor occurred 13 times, or about once a week, during the rainy season 1979 (Flores-Verdugo 1985). Both tidal and riverine flooding give rise to strong flushing of the 
lagoon. Measurements of water levels and current velocities show that the lagoon can drain to the level of the sea in a few hours when the river erodes the barrier open (Flores-Verdugo 1985). Thus, whenever the inlet is open, there is almost always a strong net water flux to the ocean because of river discharge.

The lagoon is bordered almost completely by a zone of white mangroves Laguncularia racemosa, between 10 and $50 \mathrm{~m}$ wide, with limited occurrence of the red mangrove Rhizophora mangle L. and marsh vegetation (Muehlenbergia sp.). Several species of filamentous algae (Enteromorpha sp., Chaetomorpha sp., Cladophora sp.) and the seagrass Ruppia maritima L. grow in the lagoon waters.

\section{MATERIALS AND METHODS}

The floristic composition and height of trees with diameter at breast height (DBH) greater than $2.5 \mathrm{~cm}$ were determined using the point centered quarter method (Cottam \& Curtis 1956, Cintrón et al. 1978) with points $10 \mathrm{~m}$ apart and the first point a few meters into the mangrove fringe. Transects were run at 2 sites, one of $50 \mathrm{~m}$ near the river mouth and several adjacent transects of approximately $25 \mathrm{~m}$ each about $2 \mathrm{~km}$ to the south (see Fig. 1). Several transects were necessary at the second site because the width of the mangroves did not allow for the minimum number of necessary points on one transect. At 10 additional locations equally spaced along the south branch, the width of the mangrove fringe and the percent of the canopy overhanging the water were measured. Density, basal area, and complexity index (Holdridge et al. 1971) were calculated from these data. In February 1985, 5 equally spaced transects were made along each side of the south arm of the lagoon to measure the occurrence of seedlings. The transects extended from the water's edge to the back of the mangrove fringe.

Litter fall was collected monthly from July 1979 until October 1980 in ten $1.0 \mathrm{~m}^{2}$ traps placed randomly in a white mangrove zone 0.1 ha in area near the mouth of the Quelite River. The traps were suspended above the level of highest water. Leaves and twigs were separated and dried at $65^{\circ} \mathrm{C}$ to constant weight.

Decomposition was measured as the loss of leaves from nylon litter bags ( $2.25 \mathrm{~mm}$ mesh). Thirty-six bags containing $10 \mathrm{~g}$ of dry white mangrove leaves were submerged in the channel under the overhanging canopy near the litter-fall site in October 1979, and 36 bags were placed on the floor of the mangrove swamp adjacent to the channel in December 1979. Three bags were removed each month from each site until June 1980. Sampling was terminated at this time because almost all leaves were flushed from the floor of the mangrove area and from the lagoon bottom during the wet season. The bags were rinsed to remove sediment, and the contents were dried at $65^{\circ} \mathrm{C}$ for $4 \mathrm{~d}$, weighed, and combusted at $550^{\circ} \mathrm{C}$ to constant weight to obtain ash-free dry weight (AFDW).

To investigate the fate of loose litter on the swamp floor, we placed $20 \mathrm{~g}$ dry wt of leaves in each of ten 20 $\times 20 \mathrm{~cm}$ frames with $5 \mathrm{~cm}$ sides under each litter-fall net in June 1980 before the beginning of the rainy season. Because of the location of the frames, no additional litter could fall into them. The frames were checked for remaining litter in September 1980. In June 1981, the experiment was repeated. Ten frames were placed at the same sites, and 3 frames were placed at each of 2 additional sites located farther from the inlet. At the 2 additional sites the 3 frames were evenly spaced on a transect from the water's edge to the inland extent of the mangroves. In addition to $20 \mathrm{~g}$ of litter, we placed 10 small, buoyant plastic balls in each frame. The balls at each site were of a different color to enable us potentially to follow the fate of any material leaving the swamp. The frames at all 3 sites were checked for remaining litter in September 1981. The standing biomass of leaf litter on the swamp floor was measured in June and September, 1980, in five $1.0 \mathrm{~m}^{2}$ quadrats placed randomly in the area where litter fall was measured. The leaves were dried at $65^{\circ} \mathrm{C}$ to constant weight.

The biomass of particulate organic matter greater than $2.5 \mathrm{~mm}$ on the bottom of the channel was measured monthly from July 1979 until August 1980 in 10 random samples collected by taking the top $25 \mathrm{~cm}$ of sediment from a $39 \mathrm{~cm}$ diameter plastic core and sieving the sample through a $2.5 \mathrm{~mm}$ screen in the field. The samples were dried at $65^{\circ} \mathrm{C}$ to constant weight, combusted at $550^{\circ} \mathrm{C}$ for $4 \mathrm{~h}$, and reweighed.

During each trip to the field, temperature and surface salinity were measured. Toward the end of the dry season in early June 1985, several measurements were made of soil and water salinity along the south arm of the lagoon; a time when there had been no rainfall for several months. Soil salinity was measured from wells 30 to $40 \mathrm{~cm}$ deep. Samples were collected $3.0 \mathrm{~m}$ into the mangrove fringe on the west side of the south arm about $100 \mathrm{~m}$ from the river, and 3.0 and $10.0 \mathrm{~m}$ into the mangroves on the east side of the lagoon about $3 \mathrm{~km}$ from the river (Fig. 1). A more detailed discussion of these methods is given by Flores-Verdugo (1985).

\section{RESULTS}

Water temperature in the lagoon ranged from $20^{\circ} \mathrm{C}$ in December to $35^{\circ} \mathrm{C}$ in June, reflecting the tropical climate (Fig. 2). Surface-water salinity ranged from 4 
to 35 ppt. During the dry season the salinity gradually increased from $18 \mathrm{ppt}$ in October to $35 \mathrm{ppt}$ in June. Salinity in the wet season was highly variable depending on tide and river flow. In June 1985, the surfacewater salinity of the lagoon was uniform at $30 \mathrm{ppt}$. Soil salinities at the west site and at the 3 and $10 \mathrm{~m}$ sites on the east side were 7,18 , and $18 \mathrm{ppt}$, respectively.

Laguncularia racemosa was the only species of mangrove encountered along the transects. The width of the mangrove fringe varied from 9 to $50 \mathrm{~m}$ and averaged $19 \mathrm{~m}$. Using measurements made during the transects, we estimated that about $40 \%$ of the canopy hung over the water and about $60 \%$ over the florest floor. We assumed that litter fall over the water and forest floor were in the same proportion. Mean canopy height, stem density, basal area, and complexity index are given in Table 1 . No seedlings were observed along the transects or at any other time during the study.

Total annual litter fall was $1100 \mathrm{~g}$ dry wt $\mathrm{m}^{-2}, 89 \%$ of which was leaves. Litter fall was low during the first part of the dry season (November to March) and highest in June $\left(279 \mathrm{~g} \mathrm{~m}^{-2} \mathrm{mo}^{-1}\right.$, Fig. 3). Seventy-five $\%$ of litter fall occurred in the dry season, and of this, $70 \%$ occurred in the 3 mo prior to the opening of the inlet.

Leaf decomposition was much more rapid in the bags placed in the water (Fig. 4), After 6 mo, $21 \%$ of the litter in these bags remained as compared with $73 \%$ in the bags placed on the forest floor.

All leaves placed in the litter frames on the swamp floor were washed out by September in both 1980 and 1981. All of the plastic balls in the frames also disappeared. Several searches of the area turned up only 2 balls (from the site furthest from the inlet), which were found on the beach outside the lagoon. The standing crop of leaves on the forest floor in June 1980

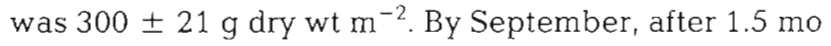
of river flow, we measured no leaf litter remaining on

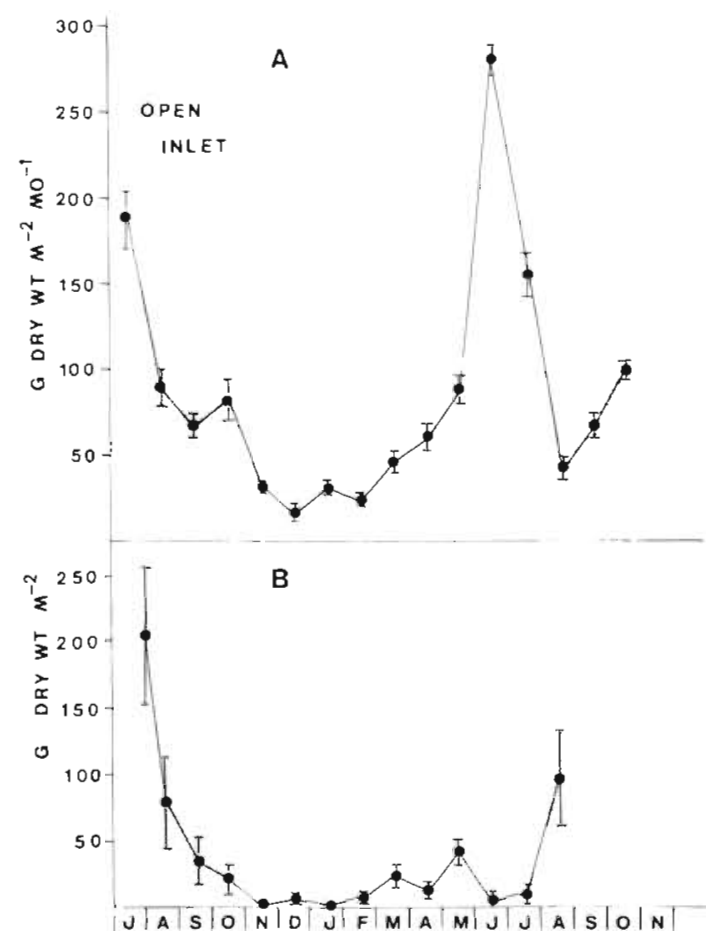

Fig. 3. (A) Monthly litter fall and (B) standing crop of particulate organic matter $(>2.5 \mathrm{~mm})$ in surficial submerged sediments. Bars: standard error. Shaded area: time when inlet was open

the swamp floor. General observations of the forest floor during the wet season indicated the virtual absence of litter. The weight of sediment particulate organic matter $(P O M)>2.5 \mathrm{~mm}$ varied from 0 to $200 \mathrm{~g}$ AFDW $\mathrm{m}^{-2}$ (Fig. 3). The weight was low during the dry season, peaked soon after the inlet opened in both 1979 and 1980, but was rapidly flushed out and/or decomposed during the wet season.

These results suggested that most of the litter fall to the forest floor during the dry season was exported to

Table 1. Structural characteristics and litter production of the El Verde mangrove forest compared to other mangrove systems in the New World tropics

\begin{tabular}{|c|c|c|c|c|c|c|}
\hline \multirow{2}{*}{$\begin{array}{l}\text { Forest } \\
\text { type }\end{array}$} & \multicolumn{5}{|c|}{ Structural characteristics } & \multirow{2}{*}{ 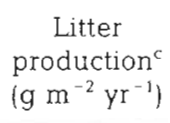 } \\
\hline & $\begin{array}{l}\text { Canopy height } \\
(\mathrm{m})\end{array}$ & $\begin{array}{l}\text { Stem density } \\
\left(\text { no } \mathrm{ha}^{-1}\right)\end{array}$ & $\begin{array}{c}\text { Basal area } \\
\left(\mathrm{m}^{2} \mathrm{ha}^{-1}\right)\end{array}$ & $\begin{array}{l}\text { No. species } \\
\text { in } 0.1 \text { ha }\end{array}$ & $\begin{array}{l}\text { Complexity } \\
\text { index }\end{array}$ & \\
\hline Riverine & $17.7 \pm 3.7$ & $1760 \pm 350$ & $41.3 \pm 8.8$ & $3 \pm .4$ & $36.4 \pm 10.3$ & $1170 \pm 170$ \\
\hline Basin & $9.0 \pm 0.7$ & $3580 \pm 394$ & $18.5 \pm 1.6$ & $2.3 \pm .2$ & $15.4 \pm 3.2$ & $730 \pm 30$ \\
\hline Fringe $^{d}$ & $8.2 \pm 1.1$ & $5930 \pm 3005$ & $17.9 \pm 2.7$ & $2.0 \pm .3$ & $14.6 \pm 4.7$ & 906 \\
\hline Dwarf & 1.0 & 25030 & 0.6 & 1 & 1.5 & 120 \\
\hline El Verde & 6 & 1800 & 9.9 & 1 & 1.1 & 1100 \\
\hline \multicolumn{7}{|c|}{$\begin{array}{l}\text { "From Pool et al. (1977) and Brown \& Lugo (1982) } \\
\text { "Canopy height } \times \text { basal area } \times \text { stem density } \times \text { no. of species }\left(0.1 \mathrm{ha}^{-1}\right) \times 10^{-5} \\
\text { "From Brown \& Lugo (1982) and Twilley }(1982)\end{array}$} \\
\hline
\end{tabular}


the lagoon due to 3 factors: (1) most litter fall occurred late in the dry season; (2) the rate of decomposition on the dry swamp floor was very low; and (3) practically all accumulated litter was rapidly flushed from the forest floor when the river began flow and the inlet opened. Therefore, we calculated an estimate of litter export from the forest floor to the lagoon using the following equation:

$$
\sum W_{\mathrm{t}}=\sum W_{\mathrm{ll}} \mathrm{e}^{-\mathrm{kt}}
$$

where $W_{t s}=$ weight remaining $t$ mo after the $i^{\text {th }}$ mo; $W_{\mathrm{L}}=$ leaf fall in the $i^{\text {th }} \mathrm{mo} ; \mathrm{k}=$ degradation coefficient for dry leaf litter; $t=$ time in mo before the inlet opens.

This calculation yields the accumulated leaf litter on the forest floor by the end of the dry season when it was all exported to the lagoon. Thus, we calculated that $76 \%$ of total litter fall during the dry season reached the lagoon waters.

\section{DISCUSSION}

The mangrove forest at El Verde presents an interesting contrast with mangrove systems studied in much earlier work. Structurally the forest is simple but production and export rates are high.

\section{Structure and composition}

The forest is composed almost completely of Laguncularia racemosa. The value for the complexity index is similar to that for dwarf forests, while the basal area is intermediate between dwarf and fringe forests (Table 1). The average height is at the lower end of the range reported by Pool et al. (1975) for fringe forests.

The almost complete dominance by Laguncularia racemosa observed at El Verde is not unusual for this type of system. We have found this to be the case in numerous lagoons with ephemeral inlets which we have visited as well as in semi-isolated mangrove systems located a considerable distance from the sea. The dominance of L, racemosa in this type of system is probably related to its less stringent habitat requirements than either black mangrove Avicennia germinans or red mangrove Rhizophora mangle and its ability to grow in any of the mangrove zones which have been described (Thom 1967, Rabinowitz 1975). Other factors which may be important are that (1) the requirements of propagule germination and seedling establishment vary for the different species of mangroves (Odum et al. 1982, Rabinowitz 1978), (2) this coast is experiencing a relative lowering of sea level, and (3) hurricanes are frequent along this coast.

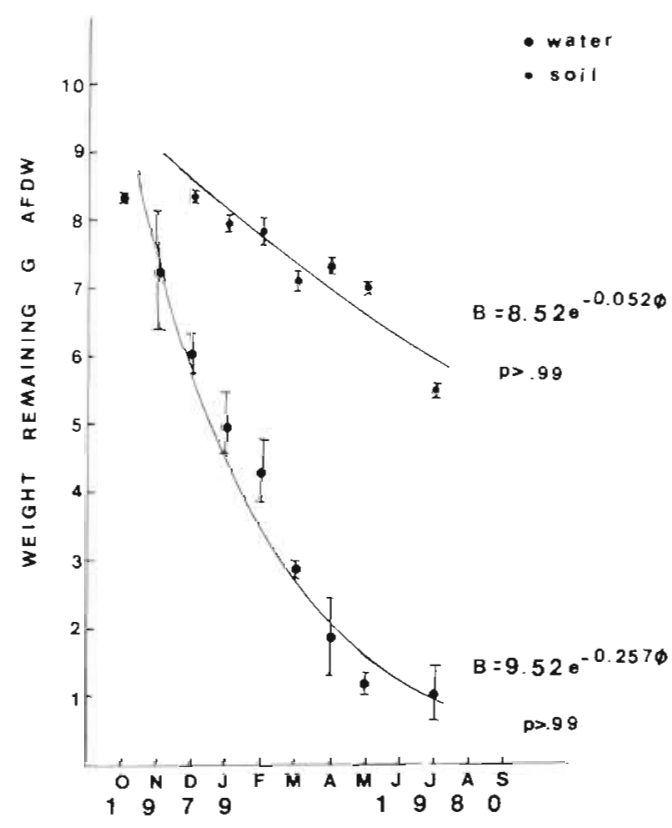

Fig. 4. Decomposition of mangrove leaves in litter bags placed on the forest floor and submerged in the adjacent channel. Bars: standard error; $\varnothing$ : time in mo; $B=$ remaining weight in $g$

A number of characteristics of propagule germination and seedling establishment suggest why Laguncularia racemosa is dominant in such ephemeral inlet systems. L. racemosa requires considerably less time for germination and root establishment than the other species of mangroves (Rabinowitz 1975, 1978). The characteristics of El Verde suggest that there is a narrow period when mangroves can become established and that $L$. racemosa is most likely to be successful. During most of the wet season propagules would be flushed from the system, while during the dry season propagules fall either on the dry forest floor or in the water; there is no exchange between these 2 areas due to lack of water flow. The short period at the end of the wet season where there is tidal flooding and low river flow, which would allow for seedling establishment, favors L. racemosa.

Another factor which may help to explain dominance by white mangroves was mentioned by Snedaker (1982). He reported that Laguncularia racemosa was the dominant species in areas experiencing a relative lowering of sea level (such as uplifting coasts and regions of recently deposited sediments). He specifically speculated that this might be the reason for dominance by $L$. racemosa in several lagoons along the southern Sinaloa coast of Mexico

The coast of Sinaloa has the highest frequency of Pacific cyclones (an average of 3 per year) along the west coast of Mexico (Secretaria de Marina 1974). A number of authors have concluded that in areas with 
high hurricane frequency, mangrove forest structure is poorly developed (Lugo \& Snedaker 1974, Lugo et al. 1976, Cintrón et al. 1978). The last hurricane which directly affected this area was in 1976

It has been reported that high soil salinity causes poorly developed mangrove forest structure (Cintrón et al. 1978), but this does not seem to be the case at $\mathrm{El}$ Verde. The low soil salinities suggest that groundwater seepage from higher elevations east of the lagoon may keep soil salinities relatively low during the dry season. The fact that the mangrove fringe is backed by a lush growth of brackish marsh support this idea. In addition, salinities in the lagoon were never hypersaline.

\section{Litter fall and decomposition}

Total litter fall of $1100 \mathrm{~g} \mathrm{~m}^{-2} \mathrm{yr}^{-1}$ for El Verde is in the upper range reported for mangroves (Lugo \& Snedaker 1974, Brown \& Lugo 1982, Odum et al. 1982, Twilley 1982), and is close to the mean reported for riverine forests (Table 1 ). Thus, even though the mangroves at El Verde have a poorly developed structure, the rate of litter production is high. This is consistent with the conclusions of Pool et al. (1975), who suggested a relationship between productivity and freshwater turnover (freshwater input divided by receiving waterbody volume) for the different forest types of Lugo \& Snedaker (1974). Dwarf forests had low productivity and low freshwater turnover, fringe and basin forests had intermediate values, and riverine forests had the highest productivity and freshwater turnover.

The mean annual discharge of the Quelite River is approximately 200 times the volume of the lagoon (and varies from 100 to 400 times) so that freshwater turnover is very high. Thus, El Verde may have a comparatively high nutrient loading despite the fact that it is located in a semi-arid region. Espinosa et al. (1981) reported similar results for mangrove systems in the state of Baja California, Mexico, where total mangrove litter fall of 948 to $1631 \mathrm{~g} \mathrm{~m}^{-2} \mathrm{yr}^{-1}$ occurred in an area with annual rainfall of only $250 \mathrm{~mm}$. It is apparent, therefore, that litter production is not necessarily correlated with mangrove forest structure. In these areas of highly seasonal rainfall, high freshwater turnover and nutrient loading apparently lead to high litter fall. Lack of water movement during the dry season, difficulty in propagule dispersion and establishment, and storms seem to inhibit the development of a robust forest structure.

Our values for litter decomposition under wet and dry conditions are similar to those reported for other mangrove areas (Odum \& Heald 1975, Day et al. 1982, Woodroffe 1982). As we mentioned earlier, the differ- ence between wet and dry decomposition has important ecological implications. Because of the seasonality of litter fall and the low rate of decomposition on the forest floor during the dry season, most of the dry season litter fall is still intact at the beginning of the wet season.

\section{Lagoon hydrology and movement of organic detritus}

The lagoon hydrology is characterized by a mixture of riverine and tidal forces. As discussed in the description of the area, when the inlet is open there is almost always a net water movement to the ocean. The floor of the mangrove zone is flushed about once a week. These hydrologic characteristics result in a strong movement of organic detritus from the mangroves to the lagoon and from the lagoon to the ocean. Our calculations indicate that $76 \%$ of mangrove litter fall during the dry season ends up in the lagoon. This is a result of low leaf decomposition on the forest floor during the dry season, the removal of essentially all accumulated litter when the river begins to flow, and the fact that about $40 \%$ of litter fall is directly to the water.

What is the fate of litter fall during the wet season? About $40 \%$ of it falls directly into the water. However, we do not definitely know the fate of litter falling to the forest floor because we did not measure decomposition during the wet season. (We stopped these measurements because of the virtual absence of litter on the floor during the wet season.) We can, however, present a range of estimates. If we assume that decomposition on the forest floor during the wet season was equal to the rate measured in the water and that there was no export until the end of the wet season (there was no litter in the litter frames at that time), then $65 \%$ of total litter fall during the wet season and $74 \%$ of total annual litter fall reached the lagoon. We believe, however, that most of the litter fall during the wet season reached the lagoon waters. As mentioned earlier, the forest floor was flooded about once a week during this study, removing most accumulated litter. If a leaf has an average life of $1 \mathrm{wk}$ on the forest floor, then it will lose $6 \%$ of its weight before being flushed out (assuming the wet decomposition rate). According to this, we calculated that $90 \%$ of annual litter fall reached the lagoon. Thus, we estimate that a minimum of $74 \%$, but probably closer to $90 \%$, of mangrove litter fall reached the lagoon waters.

We believe that a significant part of the organic detritus was also flushed to the ocean. With the initial opening of the inlet, POM in sediments near the inlet increased dramatically and then was almost completely removed (Fig. 3). We believe that this POM was 
flushed from more remote areas of the lagoon, accumulated near the inlet, and then was flushed to the ocean. The site where we measured sediment organic matter measurements was near the inlet, so it is possible that some of the mangrove litter was deposited in the more remote water areas of the lagoon. However, FloresVerdugo (1985) reported that Ruppia maritima beds, which extended 1 to $2 \mathrm{~km}$ along the south arm of the lagoon, were completely eroded at the beginning of the rainy season. We have observed this $R$. maritima flowing out of the inlet and accumulating on the ocean beach. These observations, along with the fact that the only place we found the plastic balls was on the beach, indicate that the entire system is flushed strongly and that there is probably minimal deposition on the lagoon bottom. Thus, it seems that this mangrove system which is isolated from the ocean for $8 \mathrm{mo}$ of the year is exporting the majority of its litter. For El Verde, up to $90 \%$ of total litter fall seems to be exported from the mangrove area proper and most of this is probably exported out of the lagoon. The average daily export of $2.7 \mathrm{~g} \mathrm{~m}^{-2} \mathrm{~d}^{-1}$ is considerably higher than that reported for other mangrove systems $(0.15,0.7$, and 0.7 for Florida by Brown \& Lugo 1982, Odum \& Heald 1975, and Lugo \& Snedaker 1975, respectively; 1.1 for Puerto Rico by Golley et al. 1962, and 1.2 for Australia by Boto $\&$ Bunt 1981). There has recently been criticism of export studies in general (Nixon 1980), so perhaps all of these estimates should be considered carefully. However, our present data from El Verde Lagoon suggests strongly that much of the litter fall is exported offshore. Direct flux measurements should be made to test this hypothesis further

It is possible that small coastal lagoons with ephemeral inlets such as El Verde play an important role in the dynamics of nearshore coastal ecosystems on the Pacific coast of Mexico. The productivity and export is high, this type of system is common, and the tropical ocean is very oligotrophic (Whittaker 1975). These factors suggest that these lagoons may be seasonally important in the organic budget of the close nearshore zone. Hopkinson (1985) concluded the same for nearshore waters of Georgia. Resolution of this hypothesis must, however, await more information on other coastal lagoons to determine if El Verde is a typical example, as well as more detail on the ecology of the nearshore coastal zone.

Acknowledgements. This paper is a result of a cooperative investigation sponsored by the Instituto de Ciencias del Mar y Limnología, Universidad Nacional Autónoma de México; and the Louisiana Sea Grant College Program maintained by NOAA, U.S. Department of Commerce. We thank Fernando Gonzalez Farias for his help in the field and laboratory and Bruce Williamson, Court Stevenson, and Robert Twilley for their comments on the manuscript. Contribution No. LSU-
CEI-86-02 of the Coastal Ecology Institute, Center for Wetland Resources, LSU, and No. 391 from the Instituto de Ciencias del May y Limnología, UNAM.

\section{LITERATURE CITED}

Boto, K. G., Bunt, J. S. (1981). Tidal export of particulate organic matter from a northern Australian mangrove system. Estuar. coast. Shelf Sci. 13: 247-255

Brown, S., Lugo, A. E. (1982). A comparison of structural and functional characteristics of saltwater and freshwater forested wetlands. In: Gopal, B., Turner, R. E., Wetzel, R. G., Whigham, D. F. (ed.) Wetlands ecology and management. Proceedings of the First International Wetlands Conference, New Delhi, India. National Institute of Ecology and International Scientific Publications, p. 109-130

Carter, M. R., Burns, L. A., Cavinder, T. R., Dugger, K. R., Fore, P. L., Hicks, D. B., Revells, H. L., Schmidt, I. W. (1973). Ecosystem analysis of the big cypress swamp and estuaries. U.S. Environmental Protection Agency, Region IV, Atlanta, Georgia

Cintrón, G. A., Lugo, A. E., Pool, D., Morris, G. (1978). Mangroves of arid environments in Puerto Rico and adjacent islands. Biotropica 10: 110-121

Cottam, B., Curtis, J. (1956). Use of distance measures in phytosociological sampling. Ecology $37: 451-460$

Day, J. W., Jr., Day, R. H., Barreiro, M. T., Ley-Lou, F., Madden, C. J. (1982). Primary production in the Laguna de Terminos, a tropical estuary in the southern Gulf of Mexico. Oceanologica Acta SP: 269-276

Espinosa, M., Sanchez, P., Muñoz, E. (1981). Valor energetico de los detritos y algunos aspectos sobre la productividad y degradacion de Rhizophora mangle, en tres zonas de manglar de la Bahia de la Paz. B.C.S. Center for Biological Investigations, La Paz, Baja California Sur Annual Laboratory Report, p. 137-139

Flores-Verdugo, F. J. (1985). Aporte de materia organica por los principales productos primarios a una ecosistema lagunar-estuarina de boca efimera. Ph. D. dissertation, Universidad Nacional Autónoma de México, México, D.F.

García, E. (1973). Modificaciones al sistema de clasificación climático de Köppen. Instituto de Geografia, Univ. Nacional Autónoma de México, México, D.F.

Golley, F., Odum, H. T., Wilson, R. F. (1962). The structure and metabolism of a Puerto Rican red mangrove forest in May. Ecology 43: 9-19

Holdridge, L. R., Grenke, W. C., Hathaway, W. H., Liang, T. Tosi, J. (1971). Forest environments in tropical life zones, a pilot study. Pergamon Press, New York

Hopkinson, C. S. (1985). Shallow water benthic and pelagic metabolism: evidence of heterotrophy in the nearshore Georgia Bight. Mar. Biol. 87: 19-32

Lankford, R. (1977). Coastal lagoons of Mexico, their origin and classification. In: Wiley, M. (ed.) Estuarine processes: circulation, sediments and transfer of material in the estuary, Vol. 2. Academic Press, New York, p. 182-215

Lugo, A. E., Snedaker, S. C. (1974). The ecology of mangroves. Ann. Rev. Ecol. Syst. 5: 39-64

Lugo, A. E., Snedaker, S. C. (1975). Properties of a mangrove forest in southem Florida. In: Walsh, G. E., Snedaker, S. C., Teas, H. J. (ed.) Proceedings International Symposium on the Biology and Management of Mangroves. Institute of Food and Agriculture Sciences, Univ. of Florida, Gainesville, p. 170-212

Lugo, A. E., Sell, M., Snedaker, S. C. (1976). Mangrove 
ecosystem analysis. In: Patten, B. C. (ed.) Systems analysis and simulation in ecology. Academic Press, New York, p. $113-145$

Nixon, S. W. (1980). Between coastal marshes and coastal waters - A review of twenty years of speculation and research on the role of salt marshes in estuarine productivity and water chemistry. In: Hamilton, P., MacDonald, K. (ed.) Estuarine and wetland processes. Plenum Press, New York, p. 437-525

Odum, W. E., Mclvor, C. C., Smith, T. J. (1982). The ecology of the mangroves of South Florida: a community profile. U.S. Fish \& Wildlife Serv., Office of Biological Services, Washington, D.C., FWS/OBS-81-24, p. 1-144

Odum, W. E., Heald, E. S. (1975). The detritus-based food webs of an estuarine mangrove community. In: Cronin, $\mathrm{J}$ E. (ed.) Estuarine research, Vol. 1. Academic Press, New York, p. 265-288

Pool, D. J., Lugo, A. E., Snedaker, S. C. (1975). Litter production in mangrove forests of southern Florida and Puerto Rico. In: Walsh, G. E., Snedaker, S. C., Teas, H. J. (ed.) Proceedings of the International Symposium on Biology and Management of Mangroves. Institute of Food and Agriculture Sciences, Univ. of Florida, Gainesville, p. $213-237$

Pool, D. J., Snedaker, S. C., Lugo, A. E. (1977). Structure of mangrove forests in Florida, Puerto Rico, Mexico, and Costa Rica. Biotropica 9: 195-212

Rabinowitz, D. (1975). Planting experiments in mangrove swamps of Panama. In: Walsh, G. E., Snedaker, S. C., Teas, H. J. (ed.) Proceedings of the International Symposium on Biology and Management of Mangroves. Institute of Food and Agriculture Sciences, Univ. of Florida, Gainesville, p. 385-393

Rabinowitz, D. (1978). Dispersal properties of mangrove propaguies. Biotropica 10: 47-57

Secretaria de Marina (1974). Estudio geografico de la region de Mazatlán, Sinaloa. Direccion General de Oceanografia y Señalamiento Maritimo. México, D.F.

Snedaker, S. C. (1982). Mangrove species zonation: Why? In: Sen, D. N., Rajpurohit, K. S. (ed.) Tasks for vegetation science. Dr. W. Junk Publishers, The Hague, p. 111-125

Thom, B. G. (1967). Mangrove ecology and deltaic geomorphology, Tabasco, Mexico. J. Ecol. 55: 301-343

Twilley, R. R. (1982). Litter dynamics and organic carbon exchange in black mangrove (Avicennia germinas) basin forests in a southwest Florida estuary. Ph. D. dissertation, University of Florida, Gainesville

van der Heiden, A., Hendrickx, M. E. (1982). Inventario de la fauna marina y costera del sur de Sinaloa, Mexico. Universidad Nacional Autónoma de México, Instituto de Ciencias del Mar y Limnología, Estacion Mazatlán, p. 1-135

Whittaker, R. H. (1975). Communities and ecosystems, 2nd edn. MacMillan Publ. Co., New York

Woodroffe, C. D. (1982). Litter production and decomposition in the New Zealand mangrove, Avicennia manna var. resinifera. N. Z. Jl mar. Freshwat. Res. 16: 179-188

This article was presented by Professor S. W. Nixon; it was accepted for printing on September 18, 1986 